\title{
The Effect of Picroside-2 on Erythrocyte Deformability and Lipid Peroxidation in Streptozotocin- Induced Diabetic Rats Subjected to Left Anterior Descending Artery-Ischaemia Reperfusion
}

\author{
Streptozosin ile Diyabet Oluşturulan Sıçanlarda Sol Ön İnen Arter-i̇skemi Reperfüzyonunda Pikrozid-2'nin Eritrosit \\ Deformabilitesi ve Lipid Peroksidasyonu Üzerine Etkisi
}

Faruk Metin Çomu ${ }^{1}$, Yücel Polat ${ }^{2}$, Abdullah Özer², Dilek Erer ${ }^{2}$, Mehmet Kiriş̧̧iं ${ }^{3}$ Ali Doğan Dursun ${ }^{4}$, Tolga Tatar ${ }^{2}$

Hakan Kartal ${ }^{2}$, Ayşegül Küçük ${ }^{5}$, Hakan Boyunağa ${ }^{6}$, Mustafa Arslan ${ }^{7}$

${ }^{1}$ Kirikkale University Medical Faculty, Department of Physiology, Kirikkale, Turkey
${ }^{2}$ Gazi University Medical Faculty, Department of Cardiovascular Surgery, Ankara, Turkey
${ }^{3}$ Necip Fazıl State Hospital Department of Cardiovascular Surgery, Kahramanmaras, Turkey
${ }^{4}$ Ankara University Medical Faculty, Department of Physiology, Ankara, Turkey
${ }^{5}$ Dumlupinar University Medical Faculty, Department of Physiology, Kütahya, Turkey
${ }^{6}$ Kirikkale University Medical Faculty, Department of Biochemistry, Kirikkale, Turkey
${ }^{7}$ Gazi University Medical Faculty, Department of Anaesthesiology and Reanimation, Ankara, Turkey

ABSTRACT

Aim: Diabetes mellitus (DM) is a chronic metabolic disorder principally characterized by an elevation in oxidative stress levels. Ischaemia-reperfusion (IR) injury starts a cascade of events that lead to tissue ischaemia and cellular damage produced by reperfusion causing an inflammatory like response. Erythrocyte deformability and plasma viscosity are important clinical implications for organ and tissue perfusion. Recent studies have found that picroside- 2 has antioxidant, neuroprotective and anti-inflamatory effects. The aim of our study was to investigate the effects of picroside- 2 on erythrocyte deformability and lipid peroxidation in streptozotocin-induced diabetic rats subjected to left anterior descending (LAD) artery IR.

Methods: The animals were randomly assigned to one of five experimental groups. In Group (control) C, DC (diabetes-control group), and DP (diabetespicroside-2 group) neither coronary artery occlusion nor reperfusion were performed in the control rats. In Group DIR, a branch of the LAD artery was occluded for 45 minutes followed by 90 minutes of reperfusion to produce IR. In Group DIRP, picroside-2 was administrated via $10 \mathrm{mg}^{\mathrm{kg}}{ }^{-1}$ inraperitoneal (IP) route 30 minutes before ligating the LAD artery. Serum malondialdehyde and nitric oxide activities were investigated to document lipid peroxidation and erythrocyte deformability index.

Results: Deformability index was notably increased in diabetic rats $(p<0.0001)$. It was notably increased in Group DIR when compared to Group C, DC, DP and $\operatorname{DIRP}$ ( $p<0.0001, p=0.009, p=0.013, p=0.009$, respectively). MDA level and NO activity were also higher in IR group than the other groups.

Conclusion: Erythrocyte deformability index was decreased in rats with diabetes and IR injury. This injury may lead to further microcirculatory problems. Picroside 2 was shown to be useful in reducing the side effects of this kind of injury.

Key Words: Erythrocyte deformability, myocardial ischaemia reperfusion, experimental diabetes, picroside-2, MDA, NO

Received: 12.22 .2016

\section{ÖZET}

Amaç: Diyabetes mellitus (DM), özellikle oksidatif stres seviyelerinde yükselme ile karakterize edilen kronik bir metabolik bozukluktur. İskemi-reperfüzyon (iR) hasarı, doku iskemisi ve reperfüzyonla üretilen hücresel hasara yol açan, bir dizi inflamatuar cevap benzeri olay sonucunda başlar. Eritrosit deformabilitesi ve plazma viskozitesi, organ ve doku perfüzyonu için önemli klinik belirteçlerdir. Son yıllardaki araştırmalar, pikrozid-2'nin antioksidan, nöroprotektif ve antiinflamatuar etkilere sahip olduğunu bulmuştur. Çalışmamızın amacı, streptozosin ile diyabet oluşturulan, sol ön inen (LAD) arter için îR uygulanan ratlarda pikrozid-2'nin eritrosit deformabilitesi ve lipid peroksidasyonu üzerine etkilerini araştırmaktı.

Yöntem: Hayvanlar rasgele beş gruba ayrıldı. Grup K, DK (diyabet kontrol grubu) ve DP (diyabet-pikrozid-2 grubu) ratlarında koroner arter oklüzyonu veya reperfüzyon uygulanmadı. Grup DiR'de LAD arterinin bir dalı 45 dakika boyunca kapatıldı, bunu takiben IR hasarına neden olmak için 90 dakika reperfüzyon uygulandı. Grup DiRP'de LAD arterinin bağlanmasından 30 dakika önce 10 $\mathrm{mg} \cdot \mathrm{kg}^{-1}$ intraperitoneal (IP) yolu ile pikrozid-2 uygulandı. Serum malondialdehit ve nitrik oksit aktiviteleri, lipid peroksidasyonu ve eritrosit deformabilite indeksi değerlendirildi.

Bulgular: Deformabilite indeksi diyabetik ratlarda belirgin şekilde arttı ( $p<0.0001)$. Grup DiR'de Grup K, DK, DP ve DiRP'ye kıyasla belirgin şekilde artt $(p<0.0001, p=0.009, p=0.013, p=0.009$, sırasıyla). MDA düzeyi ve NO aktivitesi iR grubunda diğer gruplardan daha yüksekti.

Sonuç: Diyabet ve IR hasarı olan ratlarda eritrosit deformabilite indeksi azaldı. Bu hasar, daha ileri mikrosirkülasyon sorunlarına neden olabilir. Pikrozid-2'nin bu tür hasarlanmanın yan etkilerini azaltmada yararlı olduğu gösterildi.

Anahtar Sözcükler: Eritrosit deformabilitesi, miyokardiyal iskemi reperfüzyonu, deneysel diyabet, pikrozid-2, MDA, NO

Geliş Tarihi: 22.12.2016

Kabul Tarihi: 20.02.2017

Address for Correspondence / Yazışma Adresi: Mustafa Arslan MD, Gazi University Medical Faculty, Department of Anesthesiology and Reanimation 06510 Ankara, Turkey E-mail: mustarslan@gmail.com

CTelif Hakkı 2017 Gazi Üniversitesi Tıp Fakültesi - Makale metnine http://medicaljournal.gazi.edu.tr/ web adresinden ulaşılabilir.

(C) Copyright 2017 by Gazi University Medical Faculty - Available on-line at web site http://medicaljournal.gazi.edu.tr/

doi:http://dx.doi.org/10.12996/gmj.2017.28 


\section{INTRODUCTION}

In last two or three decades the prevalence of diabetes mellitus (DM) has increased exponentially throughout the world, and experts estimate that it will increase by $200 \%$ in the next several decades (1-4). Diabetes mellitus (DM) is an increasingly common medical condition. Diabetes mellitus is an increasingly common disease that affects people of all ages. Diabetic patients require perioperative care more frequently and physicians need to pay extra attention to this. Premature mortality, microvascular and cardiovascular complication risk is significantly increased in patients with diabetes. These patients tend to be sicker than most non-diabetic patients; so they place a proportionally larger burden on anaesthetic services $(2,5,6)$. Thus, more careful perioperative care is necessary for these patients (7).

Diabetes has been associated with a $50 \%$ increased early mortality following coronary artery bypass graft surgery (5). Likewise, the Framingham Heart Study reported higher incidences of painless myocardial infarction in patients with diabetes than without (39\% vs $22 \%$ ) (8). Cardiac surgery with cardiopulmonary bypass is inevitably associated with a systemic inflammatory response and ischaemia-reperfusion (IR) injury affecting multiple organs $(1,2)$.

Highly reactive molecules called free radicals can cause tissue damage by reacting with polyunsaturated fatty acids in cellular membranes. Circulating red blood cells (RBC) are particularly more susceptible to oxidative stress. During IR, induced oxidative stress can result in the oxidation of lipids and can cause significant modification in RBC shape or in cell membrane with the consequent alteration of cellular deformability. Erythrocyte deformability is crucial for the maintenance of normal circulation. Optimal deformability facilitates the passage of RBC through narrow capillaries in the microcirculation and reduces blood viscosity at high shear rates in large blood vessels (9).

In vitro and in vivo studies indicate that lipid peroxidation associated with diabetic complications and that this plays a critical role in the pathogenesis of diabetic complications. So control of lipid peroxidation is very important. A variety of endogenoous and ezogenous antioxidant mechanisms serve to control this peroxidative process (10-15).

Normally, endothelial NOS synthetizes low levels of nitric oxide (NO) and it regulates vascular tone. During IR injury, the NO production increases and toxic effects of NO become prominent (16). The hemorheological parameters in DM are often disturbed. These parameters include (but are not limited to) hematocrit, plasma proteins, erythrocyte aggregation, and erythrocyte deformability (17).

Picrorhiza scrophulariiflora belongs to the plant family, Scrophulariaceae. The roots of this plant are of benefit to health and often used in traditional Chinese medicine to treat a number of conditions (18). Extracts of the roots contain various terpenoids and glycosides and picroside- 2 is one of the main active constituents of the extracts. Numerous published studies have shown that picroside-2 has a wide range of pharmacological effects, including neuroprotective, hepatoprotective, anti-apoptosis, anti-cholestatic, antiinflammatory and immune-modulating activities (19-21). Picroside-2 has also been shown to have a protective effect against IR in other organs, including the brain (22), renal (23), because of its anti-oxidative, anti-inflammatory and antiapoptotic properties.

This study aims at investigating deformability changes and picroside-2's preventive role against these changes in lipid peroxidation and erythrocytes of diabetic rats during an experimental model of myocardial IR injury.

\section{MATERIALS and METHODS}

\section{Animals and Experimental Protocol}

This study was conducted in the Laboratory Animals Raising and Experimental Researches Center (GUDAM) Laboratory of Gazi University with the consent of the Experimental Animals Ethics Committee of Gazi University. All of the procedures were performed according to the accepted standards of the Guide for the Care and Use of Laboratory Animals.

In the study, 30 male Wistar Albino rats weighing between 230 and $290 \mathrm{~g}$, raised under the same environmental conditions, were used. The rats were kept at $20-21^{\circ} \mathrm{C}$ in cycles of 12 hours of daylight and 12 hours of darkness and had free access to food until two hours before the anaesthetic procedure. The animals were randomly separated into five groups, each containing six rats.
Diabetes was induced by a single IP injection of streptozotocin (Sigma Chemical, St. Louis, MO, USA), at a dose of $55 \mathrm{mg} . \mathrm{kg}^{-1}$ body weight. The levels of blood glucose were measured for 72 hours following this injection. Rats were classified as diabetic if their fasting blood glucose (FBG) levels were over 250 $\mathrm{mg} \cdot \mathrm{dL}^{-1}$, and only animals with FBGs of $>250 \mathrm{mg} \cdot \mathrm{dL}^{-1}$ were included in the diabetic groups (diabetes only, diabetes picroside-2, diabetes plus IR and diabetes plus picroside-2-IR). The rats were kept alive for four weeks after streptozotocin injection to allow the development of chronic diabetes before they were exposed to IR [21]. The rats were weighed before the study.

Rats were anesthetized with an IP injection of $100 \mathrm{mg} \cdot \mathrm{kg}^{-1}$ of ketamine. The chest was shaved with a small animal clipper. The trachea was cannulated and artificial respiration applied. Each animal was fixed in a supine position on the operating table. The chest was opened by left thoracotomy at approximately $2 \mathrm{~mm}$ to the left of the sternum and followed by sectioning the fourth and fifth ribs. Rats were then immediately subjected to positive pressure artificial respiration with room air using a volume of $1.5 \mathrm{~mL} / 100 \mathrm{~g}$ body weight at a rate of 60 strokes/min. Sodium heparin $\left(500 \mathrm{IU} . \mathrm{kg}^{-1}\right)$ was injected via peripheral vein in the tail.

After incising pericardium, the heart was exteriorized with gentle pressure on the right side of the rib cage. An $8 / 0$ silk suture attached to a $10-\mathrm{mm}$ micropoint reverse-cutting needle was used to placed under the left main coronary artery. The heart was then carefully replaced in the chest and the animal was allowed to recover for 20 minutes.

There were five experimental groups. Group C (control; $n=6$ ), Group DC (diabetes-control; $n=6$ ), Group DP (diabetes-picroside-2), Group DIR (diabetesIR; $n=6$ ) and Group DIRP (diabetes-IR-picroside-2; $n=6$ ) underwent left thoracotomy and received IP picroside-2 (Sigma Aldrich Co. Ltd. (CAS No: 39012-20-9, purity> 98\%, molecular formül: $\mathrm{C}_{23} \mathrm{H}_{28} \mathrm{O}_{13}$ ) administrated via 10 $\mathrm{mg} . \mathrm{kg}^{-1}$ IP route 30 minutes before ligating the LAD. A small plastic snare was threaded through the ligature and placed in contact with the heart. Applying tension to the ligature could then occlude the artery (45 minutes), and reperfusion was achieved by releasing the tension ( 90 minutes). However, after the above procedure, the coronary artery was not occluded or reperfused in the control, diabetic control and diabetic picroside- 2 rats.

All the rats were given ketamine $100 \mathrm{mg}^{\mathrm{kg}} \mathrm{k}^{-1} \mathrm{IP}$ and intracardiac blood samples of rats were obtained. Erythrocyte packs were prepared using heparinized total blood samples. Deformability measurements were achieved by using erythrocyte suspensions with haematocrit level of $5 \%$ in phosphate buffered saline (PBS) buffer.

\section{Deformability Measurements}

Samples of blood were carefully taken and the measurement process was as fast as possible to avoid haemolysis of erythrocytes. The collected blood was centrifuged at $1000 \mathrm{rpm}$ for $10 \mathrm{~min}$. Serum and buffy coat on erythrocytes were removed. An isotonic PBS buffer was added to the collapsing erythrocytes and this was followed by centrifugation for $10 \mathrm{~min}$ at $1000 \mathrm{rpm}$. Liquid on the upper surface was removed. Finally, pure red cell packs were obtained from the washing process, which was repeated three times. Erythrocyte packs were mixed with the PBS buffer to generate a suspension with a value of $5 \% \mathrm{Htc}$. These erythrocyte suspensions were used for the measurement of deformability. Collection and deformability measurements of erythrocytes were performed at $22^{\circ} \mathrm{C}$.

The constant-current filtrometer system was used in the measurement of erythrocyte deformability. Samples to be measured were prepared with $10 \mathrm{~mL}$ of erythrocyte suspension and PBS buffer. The flow rate was maintained at 1.5 $\mathrm{mL} / \mathrm{min}$ with an infusion pump. A $28 \mathrm{~mm}$ nucleoporin polycarbonate filter with a $5 \mu \mathrm{m}$ pore diameter was preferred. Pressure changes while the erythrocytes passed through the filter were detected by the pressure transducer, and the data was transferred to the computer with the help of an MP30 data equation system (Biopac Systems Inc, Commat, USA). The necessary calculations were performed with related computer programs by measuring the pressure changes at various times. Pressure calibration of the system was performed before each sample measurement. The buffer $\left(P_{T}\right)$ and the erythrocytes $\left(P_{E}\right)$ were passed through the filtration system and the changes in pressure were measured. The relative refractory period value (Rrel) was calculated by relating the pressure value of the erythrocyte suspension to the pressure value of buffer. Increasing Rrel in the deformability index was interpreted to adversely affect the erythrocytes' deformability. 
Measurements of MDA levels and NO activities

Esterbauer method was applied in order to measure lipid peroxidation. Malondialdehyde reacted with thyobarbutiric acid at $90-95{ }^{\circ} \mathrm{C}$ and resulted in pink chromogranin. After 15 min specimens rapidly cooled then absorbances were read at $532 \mathrm{~nm}$ spectrophotometrically. Results were represented as nmol. $\mathrm{g}^{-1}$ tissue protein (24). NO's stable oxidative metabolites' concentrations $\left(\mathrm{NO}_{2}-\right.$ ve $\left.\mathrm{NO}_{3}-\right)$ were measured in serum and $\mathrm{NO}$ production was determined. Measurement of nitrite concentration was performed with Griess reaction (25).

\section{Statistical Analysis}

The statistical analyses were performed with SPSS 20.0 software program and $p<0.05$ was considered statistically significant. The findings were expressed as mean \pm standard error (SE). The data were evaluated with Kruskal-Wallis variance analysis. The variables with significance were evaluated with Bonferroni corrected Mann-Whithney U test.

\section{RESULTS}

Deformability index was significantly increased in diabetic rats $(p<0.0001)$, however it was similar in Group DC and DIRP $(p=0.989)$. It was significantly increased in Group DIR when compared to Group C, DC, DP and DIRP $(p<0.0001, p=0.009, p=0.013, p=0.009$, respectively) (Fig. 1). Relative resistance was increased in IR models.

MDA level was also higher in IR group than the other groups $(p=0,001, p=0,004$, $p=0,003, p=0,005$, respectively), (Figure 2). However, picroside- 2 treatment in IR-P group resulted with similar MDA levels with the C, DC, and DP groups (Figure 2)

NO activity was also higher in IR group than the other groups $(p<0,0001$, $p=0,001, p=0,030, p=0,001$, respectively), (Figure 3). However, picroside-2 treatment in IR-P group resulted with similar NO activity with the DC, DP groups (Figure 3).

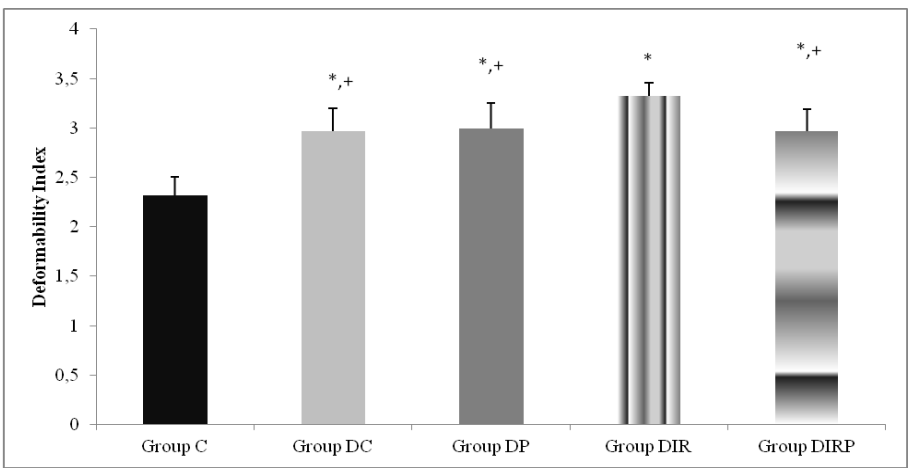

Figure 1: Erythrocyte deformability values of the groups. Each bar represents the mean $\pm \mathrm{SE}$

* $p<0.05$ compared to Group C; $+p<0.05$ compared to Group DIR

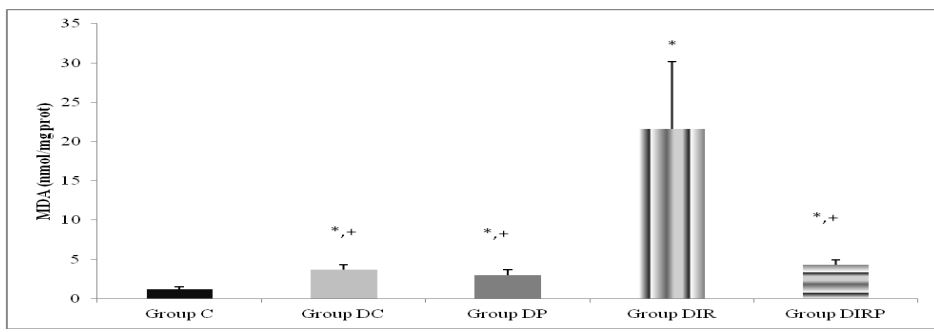

Figure 2: Malondialdehyde levels values of the groups. Each bar represents the mean $\pm \mathrm{SE}$.

* $p<0.05$ compared to Group C; + $p<0.05$ compared to Group DIR

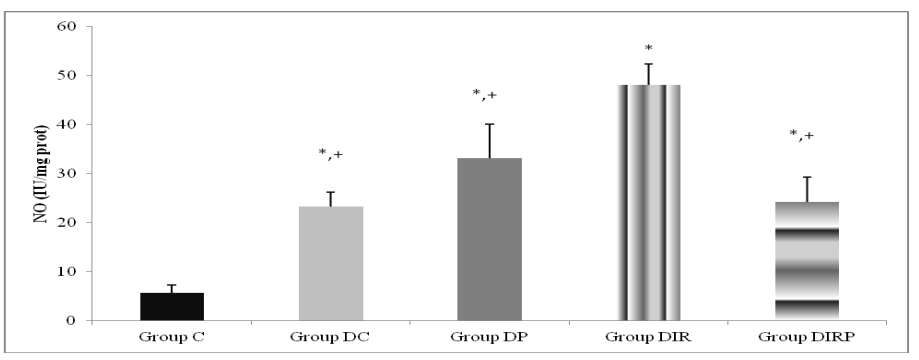

Figure 3: Nitric Oxide activity values of the groups. Each bar represents the mean $\pm \mathrm{SE}$.

* $p<0.05$ compared to Group C; + $<<0.05$ compared to Group DIR

\section{DISCUSSION}

Diabetes mellitus is a group of metabolic diseases characterized by hyperglycemia resulting from defects in insulin secretion, insulin action, or both. Diabetes mellitus has a high social and economic importance, as the number of diabetes patients continues to grow at an unprecedented rate throughout the world (26).

Lipid peroxidation causes loss of viscosity in biological membranes, decrease in membrane potential and cell injury due to increased permeability of hydrogen and other ions. One of the most important type of injury caused by free radicals is lipid peroxidation and it is measured by MDA production. It is one of the most common and well-known methods for evaluating IR injury (27).

Functional studies of the endothelium showed that hypoxia causes endothelial cell injury. Significant increase in endothelial NO release was observed after 150 seconds following re-establishment of arterial flow. NO inhibits degranulation by directly effecting GMP-cylase enzyme of the platelets and their aggregation (28).

Hemorheological parameters in DM are often disturbed. These parameters include (but are not limited to) hematocrit, plasma proteins, erythrocyte aggregation, and erythrocyte deformability (29). For migration of oxygen and vital molecules to the final organ capillaries and clearance of metabolic wastes, erythrocytes must be able to extend and curve and have the capability to move in these areas. This capacity, called "deformability", becomes more important in microcirculation. Altered erythrocyte deformability changes the erythrocytes' capacity of oxygen delivery and also helps the survival of the circulating erythrocytes (30-32).

In addition, the impaired perfusion at the tissue level observed as complication of DM has been suggested to be primarily due to reduced erythrocyte deformability $(33,34)$. Additionally, metabolic changes and tissue perfusion due to cardiovascular problems may lead to inadequate recovery in plasma viscosity (35)

Previous studies showed various pharmacologic effects of picroside- 2 such as antioxidant, antiapopitotic and antiinflamatory ones (19-23).

Cho et al. (17) demonstrated that blood viscosity was significantly high in diabetes. These results indicate that the consequent glucose elevation in blood plasma mainly affects RBCs and the vascular endothelial cells, including the capillary walls. The impaired tolerance of glucose or uncontrolled levels of blood glucose often causes microvascular complications in diabetes. Moreover, the impairment of erythrocyte deformability is attributed to the specific changes in the membrane structure. The oxidative stress due to high glucose concentrations causes damage to the erythrocyte membrane proteins, even with a relatively short exposure time (36).

Barnes et al. (37) reported that erythrocyte deformability was lower in the 14 diabetes patients with the most extensive micro-angiopathy than in the controls or the 22 diabetes patients with slight or no complications. They suggested that hyperviscosity and reduced erythrocyte deformability may be important and potentially treatable factors in the aetiology or progression of microcirculatory disease in diabetes. Similar to these previous studies, we also found that erythrocyte deformability was decreased in diabetes induced rats. 
To the best of our knowledge, ours is the first study to show that IR of the diabetic rat heart results in significant negative changes that can be observed in erythrocyte deformability and that picroside- 2 administration at the beginning of heart ischaemia can provide varying degrees of protection against the negative effects of variations in erythrocyte deformability.

As a conclusion, the results of this study clearly demonstrated that erythrocyte deformability is significantly altered in experimental myocardial IR injury in the diabetic rat. This might cause further problems in microcirculation. Thus, measurement of erythrocyte deformability might have a critical effect on the follow-up for IR injury. Additionally, picroside-2 administered before induction of ischaemia was observed to have protective effects on these alterations in myocardial IR injury. Other aspects of these findings, including clinical significance and practical applications, merit further experimental and clinical investigation.

\section{Conflict of interest}

No conflict of interest was declared by the authors.

\section{REFERENCES}

1. Robertshaw HJ, Hall GM. Diabetes mellitus: anaesthetic management. Anaesthesia 2010;61: 1187-90.

2. McAnulty GR, Robertshaw HJ, Hall GM. Anaesthetic management of patients with diabetes mellitus. Br J Anesth 2000; 85: 80-90.

3. McAnulty GR, Hall GM. Anaesthesia for the diabetic patient. Br J Anesth 2003; 88: 428-30.

4. Gu W, Pagel PS, Warltier DC, Kersten JR. Modifying cardiovascular risks in diabetes mellitus. Anesthesiology 2003;98: 774-9.

5. Giquel J, Rodriguez-Blanco YF, Matadial C, Candiotti K. Diabetes mellitus in anaesthesia. Br J Diabetes Vasc Dis 2012;12: 60-4.

6. Miller RD. Miller's Anesthesia. 7th ed. In: Roizen MF, Fleisher LA, eds. Anesthesia implications of current disease. Chicago: Year Book Medical Publishers, 2010:1067-149.

7. Kadoi Y. Anesthetic considerations in diabetic patients. Part I: preoperative considerations of patients with diabetes mellitus. J Anesth 2010; 24: 739-47.

8. Margolis JR, Kannel WS, Feinleib M, Dawber TR, McNamara PM. Clinical features of unrecognized myocardial infarction silent and symptomatic. Eighteen year follow-up: Framingham study. Am J Cardiol 1973;32: 1-7.

9. Peto K, Nemeth N, Brath E, Takacs IE, Baskurt OK, Meiselman HJ, et al. The effects of renal ischemia-reperfusion on hemorheological factors: preventive role of allopurinol. Clin Hemorheol Microcirc 2007; 37: 347-58.

10. Vincent AM, Russell JW, Low P, Feldman EL.Oxidative stress in the pathogenesis of diabetic neuropathy. Endocrine Reviews 2004; 25: 612-28.

11. Memisogullari R, Taysi S, Bakan E, Capoglu I. Antioxidant status and lipid peroxidation in Type II Diabetes Mellitus. Cell Biochem Func 2003; 21: 291-6.

12. Sacks DB. Diabetes Mellitus. In: Burtis CA, Ashwood ER, (Ed). Tietz Texbook of clinical chemistry. Philadelphia: WB Saunders Co: 1999; pp 766-76.

13. Cherubini A, Ruggiero $C$, Polidori MC, Mecocci C. Potential markers of oxidative stress in stroke. Free Radic Biol Med 2005;39: 841-52.

14. Memişoğulları R, Bakan E. Levels of ceruloplasmin, transferrin, and lipid peroxidation in the serum of patients with Type 2 diabetes mellitus. J Diabetes Complications 2004;18: 193-7.

15. Masella R, Benedetto RD, Varý R, Filesi C, Giovannini C. Novel mechanisms of natural antioxidant compounds in biological systems: involvement of glutathione and glutathionerelated enzymes. J Nutr Biochem 2005;16: 577-86.
16. Das UN. Free radicals, cytokines and nitric oxide in cardiac failure and myocardial infarction. Mol Cell Biochem 2000;215(1-2):145-52.

17. Cho YI, Mooney MP, Cho DJ. Hemorheological disorders in diabetes mellitus. J Diabetes Sci Technol 2008;2: 1130-8.

18. Li JX, Li P, Tezuka Y, Namba T, Kadota S. Three phenylethanoid glycosides and an iridoid glycoside from Picrorhiza scrophulariiflora. Phytochemistry 1998; 48: 537-42.

19. Cao Y, Liu JW, Yu YJ, et al. Synergistic protective effect of picroside II and NGF on PC12 cells against oxidative stress induced by $\mathrm{H}_{2} \mathrm{O}_{2}$. Pharmacol Rep 2007;59: 573-9.

20. Smit HF, Kroes BH, van den Berg AJ, et al. Immunomodulatory and anti-inflammatory activity of Picrorhiza scrophulariiflora. J Ethnopharmacol 2000; 73: 101-9.

21. He L, Liang M, Hou FF, et al. Ethanol extraction of Picrorhiza scrophulariiflora prevents renal injury in experimental diabetes via anti-inflammation action. J Endocrinol 2009; 200: 347-55.

22. Li $Q$, Li $Z, X u X Y$, Guo $Y L$, Du F. Neuroprotective properties of picroside II in a rat model of focal cerebral ischemia. Int J Mol Sci 2010; 11: 4580-90.

23. Wang $\mathrm{L}$, Liu $\mathrm{XH}, \mathrm{Chen} \mathrm{H}$, et al. Picroside II protects rat kidney against ischemia/reperfusion-induced oxidative stress and inflammation by the TLR4/NF-KB pathway. Exp Ther Med 9:1253-8.

24. Esterbauer $\mathrm{H}$, Cheeseman $\mathrm{KH}$. Determination of aldehydic lipid peroxidation products: malonaldehyde and 4-hydroxynonenal. Methods Enzymol 1990;186: 407-21.

25. Cortas NK, Wakid NW. Determination of inorganic nitrate in serum ana urine by a kinetic cadmium-reduction method. Clin Chem 1990 36: 1440-3.

26. Le Devehat $C$, Khodabandehlou $T$, Vimeux M. Impaired hemorheological properties in diabetic patients with lower limb arterial ischaemia. Clin Hemorheol Microcirc 2001; 25: 43-8.

27. Girn HR, Ahilathirunayagam S, Mavor Al, Homer-Vanniasinkam S. Reperfusion syndrome: cellular mechanisms of microvascular dysfunction and potential therapeutic strategies. Vasc Endovascular Surg 2007;41: 277-93.

28. Biglioli $P$, Cannata $A$, Alamanni $F$, Naliato $M$, Porqueddu $M$, Zanobini $M$, Tremoli E, Parolari A. Biological effects of off-pump vs. on-pump coronary artery surgery: focus on inflammation, hemostasis and oxidative stress. Eur J Cardiothorac Surg 2003;24: 260-9.

29. Barnes A, Willars E. "Diabetes" in Clinical Hemorheology. Chien S, Dormandy J, Ernst E, A Matrai A, eds. Dordrecht: Martinus Nijhoff 1987, pp 275-309.

30. Zinchuk VV. Erythrocyte deformability: physiological aspects. Usp Fiziol Nauk 2001; 32: 66-78.

31. Kuypers FA. Red cell membrane damage. J Heart Valve Dis 1998;7: 387-95.

32. Sivilotti ML. Oxidant stress and haemolysis of the human erythrocyte. Toxicol Rev 2004;23: 169-88.

33. Le Devehat $\mathrm{C}$, Khodabandehlou $\mathrm{T}$, Vimeux M. Relationship between hemorheological and microcirculatory abnormalities in diabetes mellitus. Diabete Metab 1994;20: 401-4.

34. Zimny S, Dessel F, Ehren M, Pfohl M, Schatz H. Early detection of microcirculatory impairment in diabetic patients with foot at risk. Diabetes Care 2001;24: 1810-4.

35. Muller R, Musikic P. Hemorheology in surgery:a review. Angiology 1987; 38: 581-92.

36. Mataseje A, Beder I, Kittova M, Okkelova J, Vazan R. The assessment of erythrocyte deformability by filtration rate. Bratisl Lek Listy 2003 104:158-60.

37. Barnes AJ, Locke P, Scudder PR, Dormandy TL, Dormandy JA, Slack J. Is hyperviscosity a treatable component of diabetic microcirculatory disease?. Lancet 1977;2:789-91. 